Research Article

\title{
Inhibition Effect of Gold (III) Theophylline Nano- complex on ALT Enzyme Activity in Human Serum of Iraqi Patients with Liver Disease
}

\author{
Mohammed Abed Jawad', Ola Kamal A Alkadir \\ ${ }^{1,2} \mathrm{Al}-$ Nisour University College, Iraq. \\ DOI: https://doi.org/10.24321/0019.5138.202164
}

\section{I $\quad \mathbf{N} \quad \mathbf{F} \quad \mathbf{O}$}

\section{Corresponding Author:}

Mohammed Abed Jawad, Al-Nisour University College, Iraq.

E-mail Id:

mohammed.a.medical.lab@nuc.edu.iq

Orcid Id:

https://orcid.org/0000-0002-0219-086X

How to cite this article:

MJ Jawad, Alkadir OKA. Inhibition Effect of Gold

(III) Theophylline Nano-complex on ALT Enzyme Activity in Human Serum of Iraqi Patients with Liver Disease. J Commun Dis. 2021;53(3):244249.

Date of Submission: 2021-08-20

Date of Acceptance: 2021-09-10

\section{$\begin{array}{lllllllll}\mathbf{A} & \mathbf{B} & \mathbf{S} & \mathbf{T} & \mathbf{R} & \mathbf{A} & \mathbf{C} & \mathbf{T}\end{array}$}

Introduction: The ultrasonic sonication approach was used to create an $\mathrm{Au}$ (III) nano complex with theophylline.

Methods: To explore and suggest the structure of the nano complex, UV-Vis spectroscopy, Fourier transform infrared (FT-IR), and carbon hydrogen and nitrogen (CHN) elemental studies were used. The FE-SEM was used to prove the nanoscale of the prepared complex and was to be less than $20 \mathrm{~nm}$. The effect of the gold nano complex (Au (THP) $(\mathrm{Cl})_{2}$ ) on alanine transaminase (ALT) activity in the serum of chronic liver disease patients was investigated.

Results: Compared to the control group, the patients with chronic liver disease with and without nano complex had a significant rise in serum levels of ALT activity $(P<0.001)$. Furthermore, in individuals with chronic liver disease who received nano complex, the blood levels of ALT activity were significantly lower than those who did not receive nano complex. The reason is that the Au nano complex aggressively interacts with carboxylic groups of important enzymes and inactivates them; further, the Au nano complex had an inhibitory effect on serum ALT activity.

Keywords: Liver Disease, Nano Complexes, Serum Alanine Transaminase

\section{Introduction}

Nanotechnology is one of the most promising technologies for imparting cutting-edge features in many scientific areas. ${ }^{1-3}$ Nanomaterials have recently received much attention due to their applications in biomedical, physiochemical, drug transport, sensing, imaging, and chemotherapy. ${ }^{4-6}$ TMCs (transition metal complexes) are a fascinating class of molecules that can be employed in practically any discipline of chemistry. ${ }^{7,8}$ TMCs are an important part of the human body's structural and functional aspects, and they play a key role in a variety of physiological and pathological processes. ${ }^{9,10}$ According to studies, ${ }^{10-14}$ nano complexes exhibit distinct physical, chemical, and biological properties. Gold $(\mathrm{Au})$ is considered an important field of research because it has a surface Plasmon resonance 
(SPR) and has a preference in clinical applications over other mineral particles in terms of biocompatibility and non-cytotoxicity, ${ }^{15}$ as well as their application in cancer treatment and imaging, genetic disease diagnosis, and photothermal therapy. ${ }^{16,17}$ Purines have also been widely explored in metal complexes. ${ }^{18-22}$ These complexes play an important role in many biological interactions. ${ }^{23,24}$ The study of transition metal complexes as medications for various human ailments has shown significant results. Transition metal complexes are the most widely used chemotherapeutic agents and contribute significantly to medical therapies. ${ }^{25}$ Alanine transaminase (ALT), also known as glutamic pyruvic transaminase, is a carrier enzyme located in the liver. ${ }^{26,27}$ The ALT function catalyses the reversible transamination process of an amino group into $\alpha$ - ketoglutarate, pyruvate, and L-glutamate. ${ }^{28}$ This enzyme is used to diagnose liver disorders because it is more selective than aspartate transaminase (AST). ${ }^{29}$ When liver damage occurs, ALT is released into the bloodstream and is increased in serum patients. As a result, the ALT is a useful tool for diagnosing liver lesions. ${ }^{30}$ In this project, we prepared theophylline (THP) with Au ion as a nano complex to study the inhibition of the serum ALT activity for patients with chronic liver disease.

\section{Experimental PART}

Standard operating procedures (SOPs) have been followed in conducting the study protocols.

\section{Materials}

Sigma-Aldrich provided all of the chemicals and solvents that were used. In addition, deionised water was used throughout the research process.

\section{Synthesis of Gold (III) Theophylline Nano Complex}

As shown in Scheme 1, a nano complex of Au (III) with theophylline (THP) as a ligand was produced utilising ultrasonic sonication. To make the sodium salt of the ligand, theophylline $(0.006 \mathrm{~mol})$ was dissolved in a $30 \mathrm{~mL}$ fresh $\mathrm{NaOH}(0.006 \mathrm{~mol})$ solution. After heating the solution to $70^{\circ} \mathrm{C}$, gold (III) chlorides $(0.003 \mathrm{~mol}$ in $30 \mathrm{~mL})$ were added to the aqueous solution. At $70^{\circ} \mathrm{C}$, the solution combination was ultrasonic sonicated for 3 hours. Following that, crystals of good grade developed after overnight incubation at room temperature. Filtered novel complex was then rinsed and dried thoroughly in the air.

Complex $\left(\mathrm{Au}(\mathrm{THP})_{2}(\mathrm{Cl})_{2}\right)$ : color: yellow; Anal. Calc. for $\mathrm{C}_{14} \mathrm{H}_{14} \mathrm{~N}_{8} \mathrm{O}_{4} \mathrm{AuCl}_{2:} \mathrm{C}, 26.84 ; \mathrm{H}, 2.24 \mathrm{~N}, 17.89 ; \mathrm{Au}, 31.47$. Found: C, 25.43; H, 2.11; N, 18.32; Au, 30.53\%.

\section{Specimen Collection}

Before any procedure, each patient provided with written informed consent and approval for this study was obtained by the ethical committee of Al-Nisour University College.

The blood samples were taken at random from 35 patients in Baghdad, Iraq that had liver disease, independent of their age or gender, and 35 controls were included in the study. These samples were drawn with plastic disposable syringes and allowed to clot at room temperature for 30 minutes before centrifuged at $700 \mathrm{~g}$ for 15 minutes to separate the components. The serum was extracted from the clots and placed in disposable tubes right away. The automation analyser was used to determine the amount of ALT. The serum samples were extracted and immediately deposited in plastic tubes, then stored at $\left(-20^{\circ} \mathrm{C}\right)$ to study later.

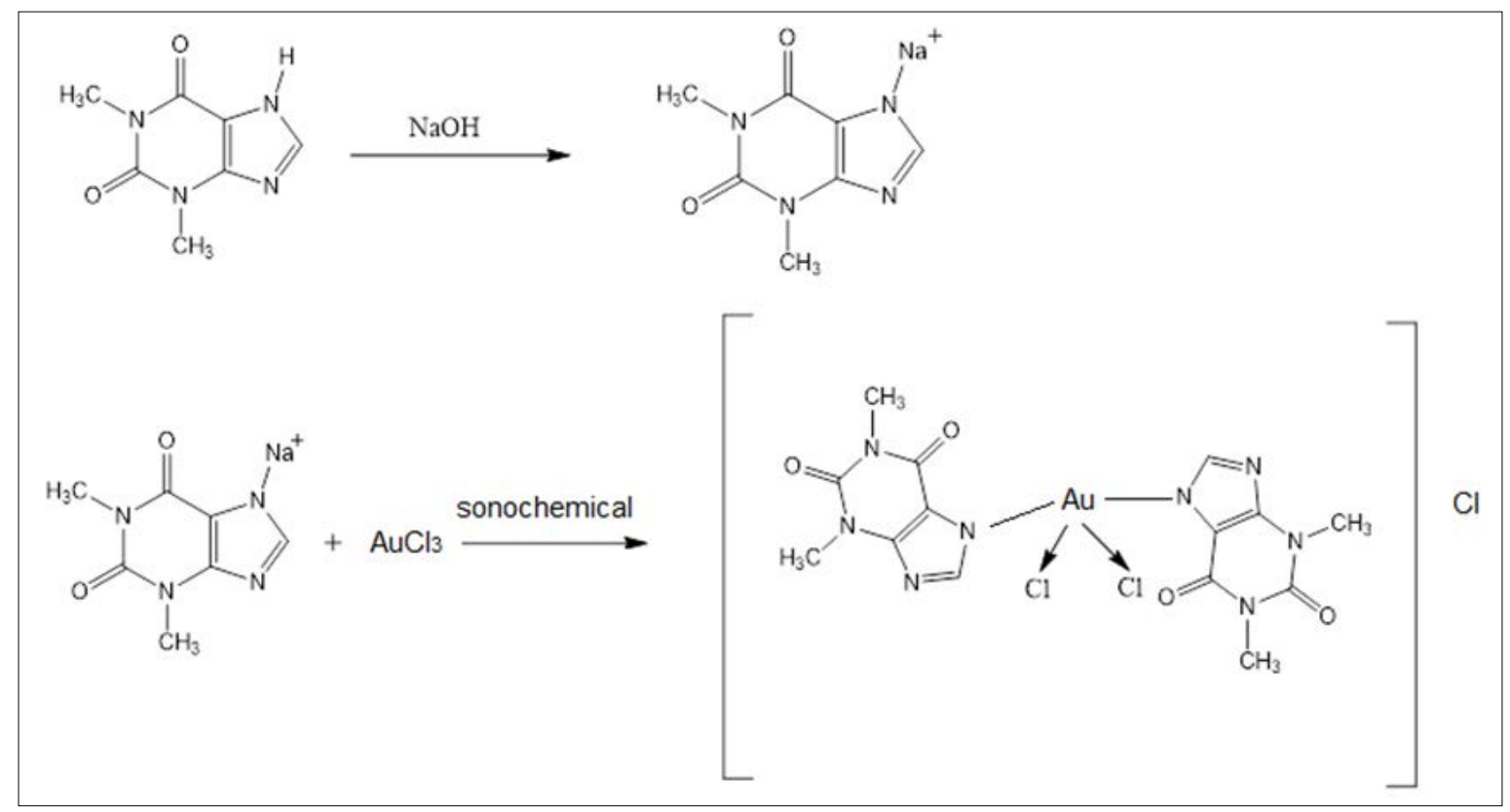

Scheme I.Gold (III) Nano Complex Synthesised 


\section{Characterisation}

Some devices characterised gold nano complex. The U.VVis spectrum, FT-IR spectra, FESEM and CHN Elemental analysis were used to investigate and suggest the structure of the Nano complex.

\section{Statistical Analysis}

The statistical study results were performed using one-way ANOVA and Microsoft Office (SPSS version 24). The results were presented as mean, standard deviation (SD), with a significance level of $p=0.01$ regarded as highly significant.

\section{Results and Discussion}

\section{FTIR Spectroscopy Analysis}

Theophylline's FTIR spectrum Figure 1 revealed an absorption band at $\left(3110 \mathrm{~cm}^{-1}\right)$ corresponding to $v(\mathrm{NH})$, which vanished in the FTIR spectra of gold nano complex Figure 2. This revealed that the $(\mathrm{NH})$ group was involved in the theophylline-gold ion coordination. At $560-575$ $\mathrm{cm}^{-1}$, a new band in the complex emerged, referring to metal coordination ( $\mathrm{N}-\mathrm{Au}$ ). In addition, due to hydrogen interactions formed by water molecules with the carbonyl and amine groups, all vibration bands in the nano complex moved to a lower frequency than in free theophylline. ${ }^{31}$

\section{UV Spectrophotometry Study}

There were UV-visible absorption ranges of theophylline and its gold Nano complex (III) between 200 and 800 $\mathrm{nm}$ in hot water. Theophylline's UV-visible spectrum has three UV-region bands. At $276 \mathrm{~nm}$, the first band can be attributed to the transition from $\pi \rightarrow \pi^{*}$. At 296 and 305 $\mathrm{nm}$, the second and third bands are assigned to a single pair's oxygen and nitrogen electrodes as shown in Figure 3. These transitions are moved to higher values in the electronic spectrum of the nano-complex. Therefore, the compound has three 513, 349 and $311 \mathrm{~nm}$ absorption ranges attributed to ${ }^{1} \mathrm{~A}_{1} \mathrm{~g} \rightarrow{ }^{1} \mathrm{~A}_{2} \mathrm{~g},{ }^{1} \mathrm{~A}_{1} \mathrm{~g} \rightarrow{ }^{1} \mathrm{~B}_{1} \mathrm{~g}$ and ${ }^{1} \mathrm{~A}_{1} \mathrm{~g} \rightarrow$ ${ }^{1} \mathrm{Eg}$ transitions. The placements of these bands correspond to the low-spin square square-planar geometry. ${ }^{32}$

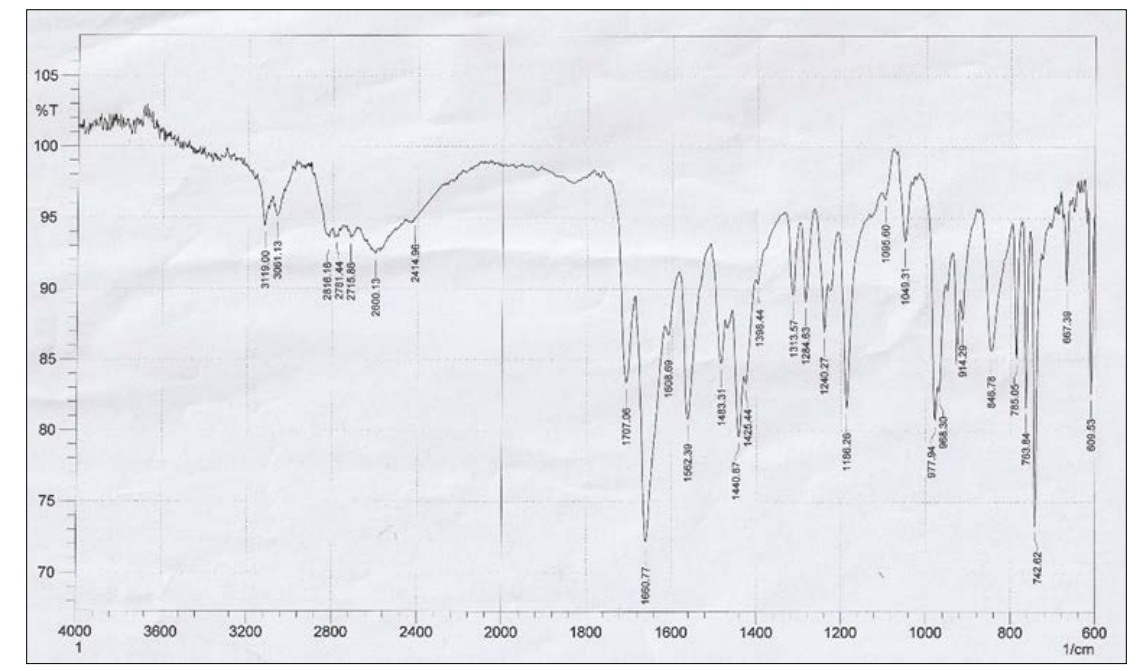

Figure I.FTIR Spectrum of Theophylline (THP)

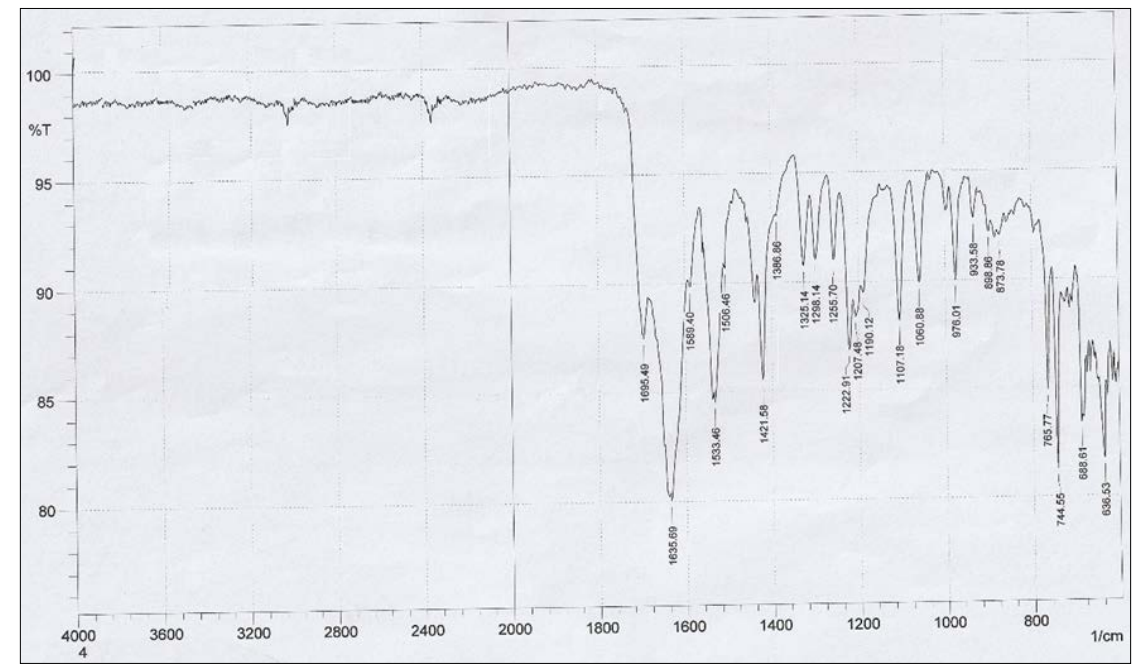

Figure 2.FTIR Spectrum of the $\left[\mathrm{Au}(\mathrm{THP})_{2}(\mathrm{Cl})_{2}\right]$ Nano Complex 

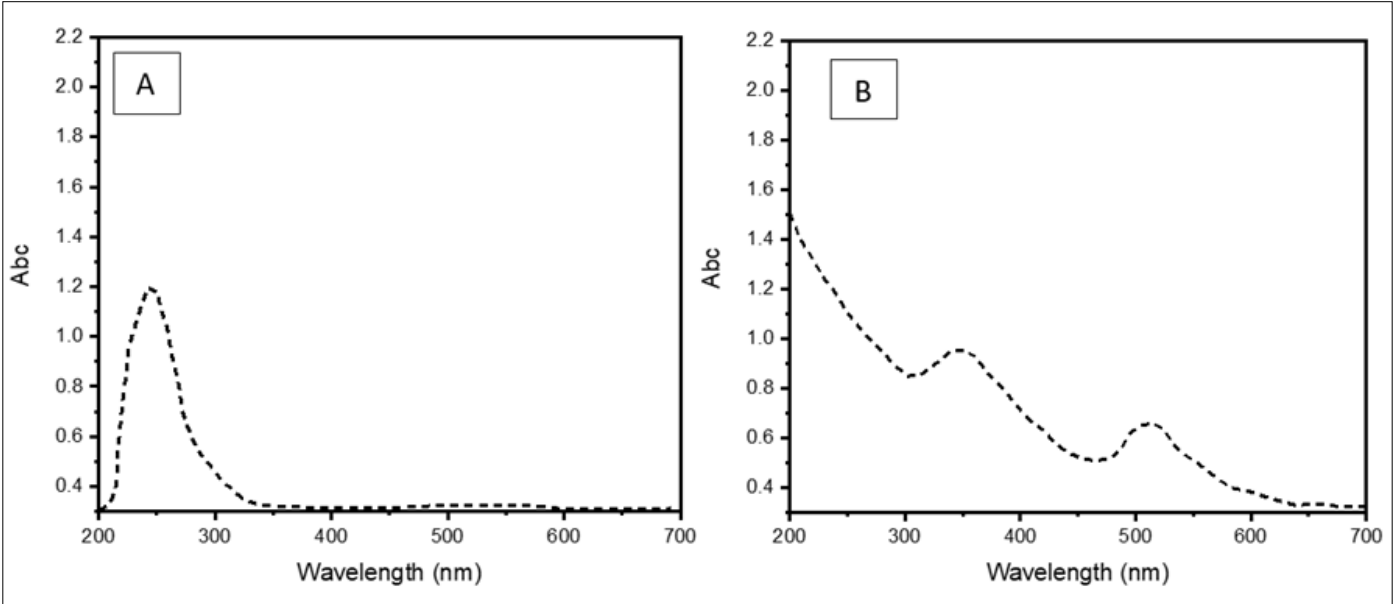

Figure 3.UV-Vis Spectra of A) Free Theophylline and B) $\left[\mathrm{Au}(\mathrm{THP})_{2}(\mathrm{Cl})_{2}\right]$ Nano Complex
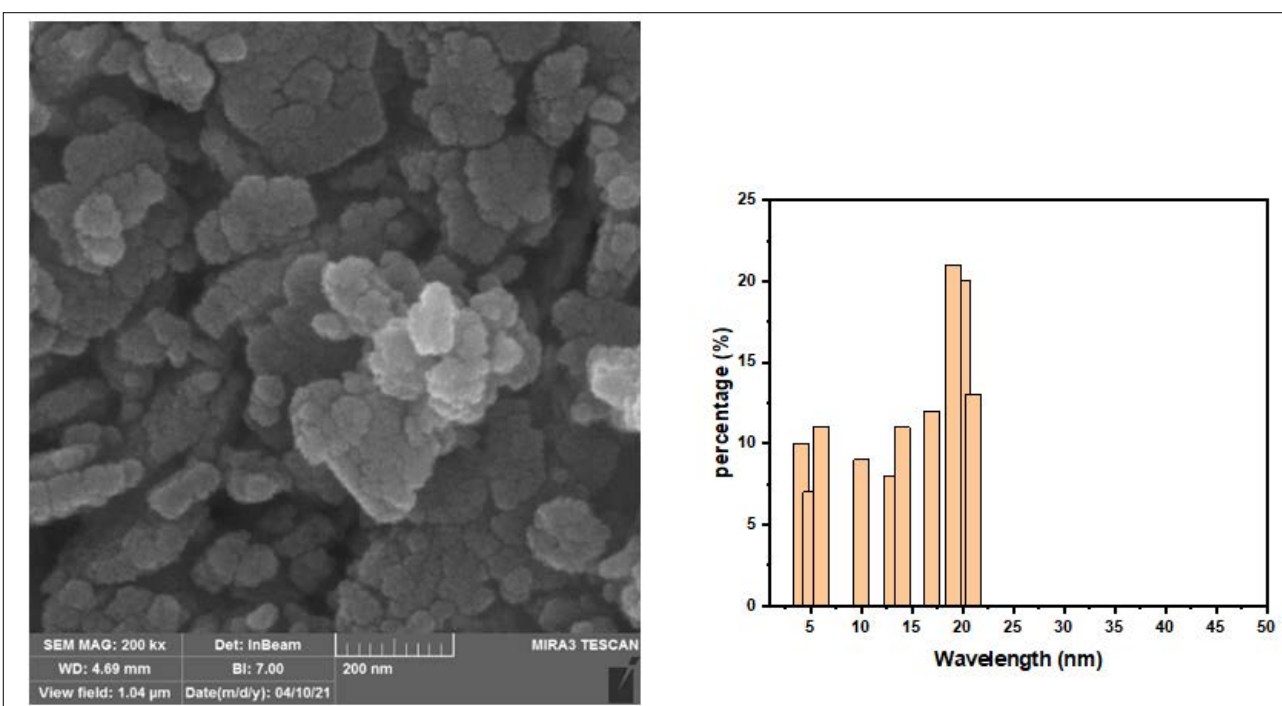

Figure 4.FESEM of $\left(\mathrm{Au}(\mathrm{THP})_{2}(\mathrm{Cl})_{2}\right)$ Nano Complex

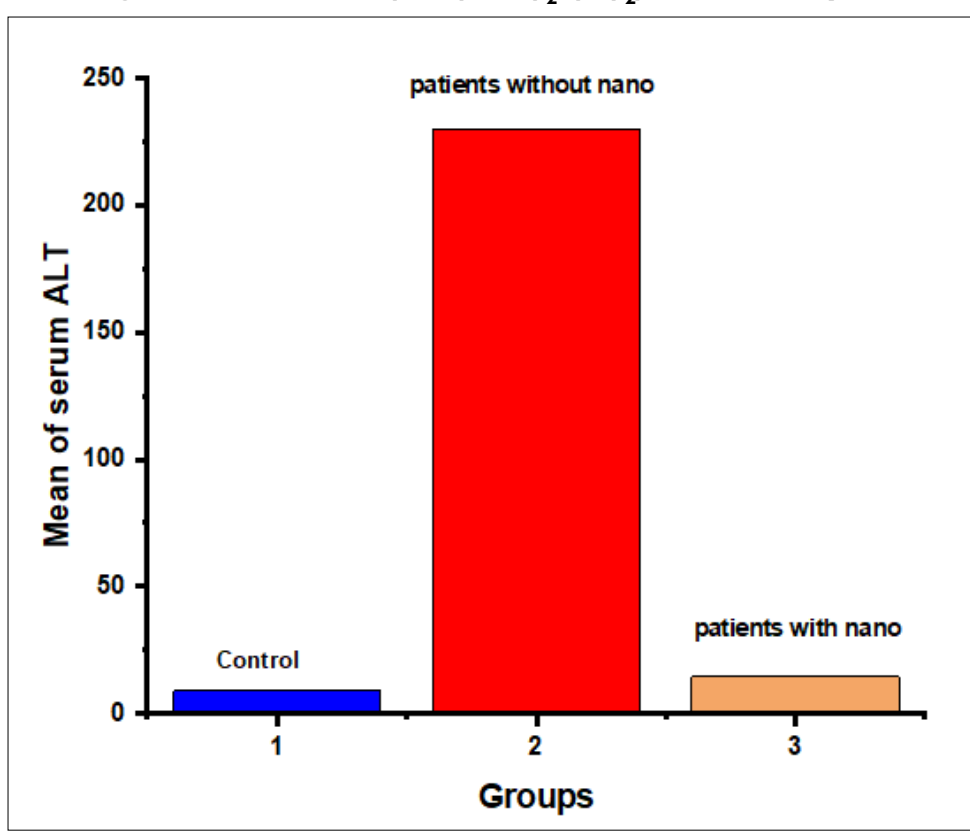

Figure 5.ALT Level of Controls and Chronic Liver Disease 


\section{FESEM Study}

FESEM was used to analyse the surface morphology of the sample. The microscopy examination revealed that the synthesised complex was not in direct contact with the aggregates, indicating that the complex had stabilised. The majority of the synthesised Au nano complexes had spherical and irregular forms. The morphological shapes and sizes of the aggregations were defined using fractal dimensions and the box-counting approach. ${ }^{33} \mathrm{~A}$ representative FESEM micrograph revealed a particle size range of $10-20 \mathrm{~nm}$ (Figure 4).

\section{Effect of $\left[\mathrm{Au}(\mathrm{THP})_{2}(\mathrm{Cl})_{2}\right]$ Nano Complex on Alanine Transaminase (ALT) Enzyme Activity}

Table 1 shows the effect of gold nano complex on ALT enzyme activity in human serum of patients with chronic liver disease in the current investigation. According to the results of the automated analyser, there was a highly significant increase in serum levels of ALT activity in patients with chronic liver disease with and without nano complex as compared to the control group $(P<0.001)$. In individuals with chronic liver disease who received nano complex, blood levels of ALT activity were significantly lower than those who did not receive nano complex. This is due to the nano complexes' interaction with the enzyme's carboxylic group, which results in inhibition as shown in Figure 5.

Table I.Alanine Transaminase Level in Sera of Controls and Chronic Liver Patients

\begin{tabular}{|c|c|c|}
\hline Groups & $\begin{array}{c}\text { Alanine transaminase } \\
\text { (Mean } \pm \text { SD) }\end{array}$ & p-value \\
\hline Control & $8.85 \pm 2.42$ & $\mathrm{p}<0.001$ \\
\hline $\begin{array}{c}\text { Patients without } \\
\text { nano complex }\end{array}$ & $230 \pm 27.4$ & $\mathrm{p}<0.001$ \\
\hline $\begin{array}{c}\text { Patients with } \\
\text { nano complex }\end{array}$ & $14.5 \pm 3.46$ & $\mathrm{p}<0.001$ \\
\hline
\end{tabular}

The results are of high importance in individuals with chronic liver disease who received nano complex this attribute to Au nano complex had an inhibitory effect on serum ALT activity and so minimising liver cell damage and might be used as a cell protectant agent but need more research on cell toxicity.

\section{Conclusion}

Complexes in nanoscale were synthesised using the ultrasonic sonication approach. Therefore, the nano complex may be easily manufactured without aggregation using our approach. The current study is the first to describe how the gold nano complex affects Alanine transaminase (ALT) activity in serum from Iraqi chronic liver disease patients.
The results revealed that $\left(\mathrm{Au}(\mathrm{THP})_{2}(\mathrm{Cl})_{2}\right)$ in nanoscale had a significant inhibitory effect on enzyme activity.

Funding: Self-funding

\section{Conflict of Interest: None}

\section{References}

1. Rheima AM, Aboud NA, Jasim BE, Ismail AH, Abbas ZS. Synthesis and structural characterization of $\mathrm{ZnTiO}_{3}$ nanoparticles via modification sol-gel prosses for assessment of their antimicrobial activity. Int J Pharm Sci Res. 2021;13(1):342-7. [Google Scholar]

2. Rheima AM, Mahmood RS, Hussain DH, Abbas ZS. Study the adsorption ability of alizarin red dye from their aqueous solution on synthesized carbon nanotubes. Dig J Nanomater Biostruct. 2021;16(1):11-8. [Google Scholar]

3. Hussain DH, Rheima AM, Jaber SH. Cadmium ions pollution treatments in aqueous solution using electrochemically synthesized gamma aluminum oxide nanoparticles with DFT study. Egypt J Chem. 2020;63(2):417-24. [Google Scholar]

4. Salman AT, Ismail AH, Rheima AM, Abd AN, Habubi $\mathrm{NF}$, Abbas ZS. Nano-synthesis, characterization and spectroscopic studies of chromium (III) complex derived from new quinoline-2-one for solar cell fabrication. J Phys Conf Ser. 2021;1853(1):012021. [Google Scholar]

5. Rheima AM, Mohammed MA, Jaber SH, Hameed SA. Adsorption of selenium ( $\mathrm{Se} 4+$ ) ions pollution by pure rutile titanium dioxide nanosheets electrochemically synthesized. Desalination Water Treat. 2020 Aug;194(2020):187-93. [Google Scholar]

6. Ismail AH, Al-Bairmani HK, Abbas ZS, Rheima AM. Nano-synthesis, spectroscopic characterisation and antibacterial activity of some metal complexes derived from Theophylline. Egypt J Chem. 2020;63(7):1-5. [Google Scholar]

7. Ismail AH, Al-Bairmani HK, Abbas ZS, Rheima AM. Nano metal-complexes of theophylline derivative: synthesis, characterization, molecular structure studies, and antibacterial activity. IOP Conf Ser Mater Sci Eng. 2020 Nov;928(5):052028. [Google Scholar]

8. Ismail AH, Al-Bairmani HK, Abbas ZS, Rheima AM. Synthesis, characterization, spectroscopic and biological studies of $\mathrm{Zn}$ (II), $\mathrm{Mn}$ (II) and Fe (II) theophylline complexes in nanoscale. Nano Biomed Eng. 2020;12(3):253-61. [Google Scholar]

9. Ismail AH, Al-Bairmani HK, Abbas ZS, Rheima AM. Nanoscale synthesis of metal (II) theophylline complexes and assessment of their biological activity. Nano Biomed Eng. 2020;12(2):139-47. [Google Scholar]

10. Rheima A, Anber AA, Shakir A, Salah Hammed A, Hameed $S$. Novel method to synthesis nickel oxide 
nanoparticles for antibacterial|'activity. Iran J Phys Res. 2020 Nov;20(3):51-5. [Google Scholar]

11. Rheima AM, Mohammed MA, Jaber SH, Hameed SA. Synthesis of silver nanoparticles using the UVirradiation technique in an antibacterial application. J Southwest Jiaotong Univ. 2019;54(5). [Google Scholar]

12. Mohammed MA, Rheima AM, Jaber SH, Hameed SA. The removal of zinc ions from their aqueous solutions by $\mathrm{Cr}_{2} \mathrm{O}_{3}$ nanoparticles synthesized via the UV-irradiation method. Egypt J Chem. 2020 Feb;63(2):5-6. [Google Scholar]

13. Rheima AM, Mohammed MA, Jaber SH, Hasan MH. Inhibition effect of silver-calcium nanocomposite on alanine transaminase enzyme activity in human serum of Iraqi patients with chronic liver disease. Drug Invent Today. 2019 Nov;12(11). [Google Scholar]

14. Kadhum HA, Salih WM, Rheima AM. Improved PSi/c-Si and $\mathrm{Ga} / \mathrm{PSi} / \mathrm{c}-\mathrm{Si}$ nanostructures dependent solar cell efficiency. Applied Physics A. 2020 Oct;126(10):1-5. [Google Scholar]

15. Rheima AM, Hussain DH, Abed HJ. Fabrication of a new photo-sensitized solar cell using $\mathrm{TiO}_{2} \backslash \mathrm{ZnO}$ nanocomposite synthesized via a modified solgel technique. IOP Conf Ser Mater Sci Eng. 2020 Nov;928(5):052036. [Google Scholar]

16. Rheima AM, Anber AA, Abdullah HI, Ismail AH. Synthesis of alpha-gamma aluminum oxide nanocomposite via electrochemical method for antibacterial activity. Nano Biomed Eng. 2021 Jan;13(1):1-5. [Google Scholar]

17. Rheima AM, Mohammed MA, Jaber SH, Hameed SA. Adsorption of selenium ( $\mathrm{Se} 4+$ ) ions pollution by pure rutile titanium dioxide nanosheets electrochemically synthesized. Desalination Water Treat. 2020 Aug;194(2020):187-93. [Google Scholar]

18. Kamil AF, Abdullah $\mathrm{H}$, Rheima AM, Mohammed SH. Photochemical synthesized $\mathrm{NiO}$ nanoparticles based dye-sensitized solar cells: a comparative study on the counter electrodes and dye-sensitized concentrations. J Ovonic Res. 2021 May;17(3):299-305.

19. Kumar D, Jain V, Rai B. Imidazole derivatives as corrosion inhibitors for copper: a DFT and reactive force field study. Corro Sci. 2020 May:108724. [Google Scholar]

20. Müller J. Nucleic acid duplexes with metal-mediated base pairs and their structures. Coord Chem Rev. 2019 Aug;393:37-47. [Google Scholar]

21. Rheima AM, Anber AA, Abdullah HI, Ismail AH. Synthesis of alpha-gamma aluminum oxide nanocomposite via electrochemical method for antibacterial activity. Nano Biomed Eng. 2021 Jan;13(1):1-5. [Google Scholar]

22. Vakarov SA, Gruzdev DA, Levit GL, Krasnov VP, Charushin VN, Chupakhin ON. Synthesis of enantiomerically pure 2-aryloxy carboxylic acids and their derivatives. Russ Chem Rev. 2019;88(10):1063. [Google Scholar]
23. Castilho N, Gabriel P, Camargo TP, Neves A, Terenzi $\mathrm{H}$. Targeting an artificial metal nuclease to DNA by a simple chemical modification and its drastic effect on catalysis. ACS Med Chem Lett. 2019 Aug;11(3):286-91. [PubMed] [Google Scholar]

24. Al-Jbouri AMS, Abood FM, Hindi NKK, Alkaim AF. Evaluation of antimicrobial activity of the aquatic extract against bacterial isolates from periodontitis in Babylon Province, Iraq. Biochem Cell Arch. 2018;18:1345-50. [Google Scholar]

25. Kadhim MM, Kubba RM. Theoretical investigation on reaction pathway, biological activity, toxicity and NLO properties of diclofenac drug and its ionic carriers. Iraqi J Sci. 2020;61(5):936-51. [Google Scholar]

26. Al-Duhaidahawi DL, Jabir MS, Al-Amiery AA, Moneim AEA, Alkaim AF, Kadhum AAH. Novel antioxidants compounds derived from isatine. Biochem Cell Arch. 2018;18(1):709-13. [Google Scholar]

27. Wang CS, Chang TT, Yao WJ, Wang ST, Chou P. Impact of increasing alanine aminotransferase levels within normal range on incident diabetes. J Formos Med Assoc. 2012 Apr;111:201-8. [PubMed] [Google Scholar]

28. Bott AJ, Maimouni S, Zong WX. The pleiotropic effects of glutamine metabolism in cancer. Cancers (Basel). 2019 Jun;11(6):770. [PubMed] [Google Scholar]

29. Evalde N, James PO, Onuorah OA, Ilo CC, Okeowhor D, Cosmas S, Durojaye OA. Clinical diagnosis of disease states using enzymes and proteins. Asian J Biochem Genet Mol Biol. 2018;1:1-6. [Google Scholar]

30. Caldwell H. Preventing, identifying and treating hepatitis C. Nurs Stand. 2019 Jan;34:68-74. [PubMed] [Google Scholar]

31. Gacki M, Kafarska K, Pietrzak A, Korona-Glowniak I, Wolf WM. Synthesis, characterisation, crystal structure and biological activity of metal (II) complexes with theophylline. J Saudi Chem Soc. 2019;23(3):346-54. [Google Scholar]

32. Kumar VG, Gokavarapu SD, Rajeswari A, Dhas TS, Karthick V, Kapadia Z, Shrestha T, Barathy IA, Roy A, Sinha $S$. Facile green synthesis of gold nanoparticles using leaf extract of antidiabetic potent Cassia auriculata. Colloids Surf B Biointerfaces. 2011 Oct;87(1):159-63. [PubMed] [Google Scholar]

33. Park JH, Kim CS, Yoo DH, Yang HS, Hong KS, Moon BK, Choi BC, Lee HS. Physical properties of shape-controlled $\mathrm{TiO}_{2}$ nanoparticles. J Korean Phys Soc. 2005;47:884-8. [Google Scholar] 